\title{
Szkice
}

\section{Uśmiech Widma bez Ciała: kabalistyczna baśń z Derridą w tle}

Agata Bielik-Robson

TEKSTY DRUGIE 2016, NR 2, S. 15-37

DOI: $10.18318 /$ td.2016.2.2

Dodobno Lewis wymyślił Kota z Cheshire na podstawie prawdziwej historii o duchach. Jego przyjaciółka z Oksfordu opowiedziała mu zdarzenie, którego w żaden sposób nie potrafiła wyjaśnić. Kiedyś wybrała się na spacer w okolice Congleton, niewielkiej mieściny w hrabstwie Cheshire, żeby odwiedzić ruiny tamtejszego zamku. U wejścia do grodu zobaczyła białego kota, którego chciała pogłaskać, ale kiedy tylko się do niego zbliżyła, ten po prostu zniknął - choć nie od razu, bo zaczął się jakby rozpływać, począwszy od ogona. Zdumiona i wzburzona wróciła do miasteczka, gdzie od aptekarki dowiedziała się, że widziała „ducha kota z Congleton”, znaną tam dobrze atrakcję turystyczną. Lewis, zachwycony tą opowieścią, od razu stworzył najsłynniejszą kreację z całej menażerii wonderland: istotę, która znika, poczynając od ogona, aż na koniec zostaje tylko jego uśmiech - uśmiech widma bez ciała.

Wymyślono już wiele metafor, by opisać, co dzieje się z Bogiem po „śmierci Boga”: wydarzeniu, które otwarło drogę nowożytnej zachodniej sekularyzacji. Ale na najlepszą chyba wpadł mój chiński student
Agata Bielik-Robson - zamieszkała w Warszawie i Nottingham. Pracuje w Instytucie Filozofii i Socjologii PAN oraz jako profesor Jewish Studies na Wydziale Teologii i Religioznawstwa w University of Nottingham. Opublikowała kilkadziesiąt artykułów w językach polskim, niemieckim, francuskim i angielskim oraz dziewięć książek z zakresu współczesnej filozofii podmiotu, teorii literatury oraz filozofii religii, ze szczególnym uwzględnieniem dziedzictwa żydowskiego.

\section{http://rcin.org.pl}


z Nottingham, który po raz pierwszy usłyszał historię o zachodnim procesie „zanikania Boga” i natychmiast skojarzył ją ze swoją ulubioną bajką, czyli Alicją w krainie czarów. W pracy semestralnej (za którą rzecz jasna dostał u mnie szóstkę) przyrównał zanikającego Boga do Kota z Cheshire, brawurowo podtrzymując tę metaforę od początku do końca. Bo też w modernitas Bóg istotnie wymazuje się jakby od ogona. Najpierw, czyli już w momencie kryzysu nominalistycznego późnej scholastyki, znikają uniwersalia pośredniczące między nim a stworzonym światem; potem znika jego korpus, a więc jego bezpośrednia obecność w świecie; następnie rozpływa się jego oblicze, przechodząc w fazę hester panim, ,zakrytego oblicza”, deus absconditus, Boga Ukrytego; a na sam koniec nie ma już nawet tego i zostaje tylko - sam uśmiech.

Student z Chin nie miał przy tym pojęcia, że jego Bóg z Cheshire to jednak nie tylko metafora. Nie przeczuwał nawet, jak bardzo opis ten pasuje do losów boskości opowiedzianych w tzw. kabale luriańskiej, której ostatni rozdział dopisał nie tak dawno sam „rebe Derrisa”, czyli Jacques Derrida. Sanford Drob, drugi obok Elliota Wolfsona tropiciel motywów kabalistycznych w filozofii współczesnej, zaczyna swój esej o Derridzie taką oto anegdotą: „Podobno Levinas, w trakcie jednego z ostatnich spotkań z Derridą, domagał się od niego, żeby ten wreszcie się przyznał, że jest w istocie ostatnim wyznawcą kabały luriańskiej. Dowiedziałem się o tym od teologa śmierci Boga,Thomasa Altizera, który powiedział mi, że usłyszał o tym od Hillisa Millera, kiedy ten przedstawił Altizera samemu Derridzie". Czy to zatem prawda - nie wiadomo. Jeśli jednak tak, to intuicja Levinasa była jak najbardziej słuszna: gros myśli Derridy to wariacje na temat cimcum, czyli wielkiego wycofywania się Boga, który na koniec staje się tym samym, co Kot z Cheshire: uśmiechem bezcielesnego widma'.

Cała ta historia - i jako opowieść, i jako dzieje zachodniej nowożytności zaczynają się od i kończą na uśmiechu. Sam początek to słynna przypowieść talmudyczna z Bava mecia, wielokrotnie opowiadana przez Scholema i Levinasa, która - jak donoszą studenci Derridy (kolejna plotka) - nieodmiennie go śmieszyła. Obraz Boga, który, jak mawiał Leśmian, „ulatuje w obce dla nas strony” i z uśmiechem rzuca na odchodnym: „Pokonały mnie moje dzieci,

1 Na temat kabalistycznych elementów u Derridy por. bardzo kompetentny tekst E.R. Wolfsona Assaulting the Border: Kabbalistic Traces in the Margins of Derrida, "J) Jurnal of the American Academy of Religion" Sept. 2002 vol. 70, no 3, s. 475-514. Por. także S.L. Drob Tzimtzum and 'Differance': Derrida and the Lurianic Kabbalah, Drob.webarchive.

\section{http://rcin.org.pl}


pokonały...", to zaklęty w micie proces cimcum, przez filozofię religii tłumaczony jako boska rezygnacja z suwerenności na rzecz świata stworzonego: scedowane dziedzictwo ${ }^{2}$. Stwórca wycofuje się z bytu, który odtąd rządzi się swoimi własnymi prawami, ale jednak - inaczej niż w radykalnym deizmie nie znika całkiem: pozostaje jego ślad, właśnie w postaci tego pożegnalnego uśmiechu, uśmiechniętego $a$-dieu. Tylko z pozoru zatem Derridiańskie widmo, które „nawiedza żywych", jest duchem, jakiego należałoby się bać; Derridzie w żaden sposób nie zależy na podtrzymaniu boskiej groźnej suwerenności, choćby w postaci śladowej. Derridiańskie widmo krążące nad światem nie ma już w sobie nic z pradawnego tremens et fascinans, które udzielało się pogańskiemu sacrum. To zupełnie inne widmo, które nawiedza śmiechem: tym szczególnym oui-rire, „tako-śmiechem”, o którym Derrida pisze w innym, mniej znanym tekście widmontologicznym poświęconym Joyce'owi: Ulysse gramophone: Oui-dire de Joyce ${ }^{3}$.

To chyba najbardziej niezwykły tekst w karierze Derridy. Napisany z okazji zjazdu światowej organizacji joyce'ologów, na pozór traktuje o wielkim dziele, prawie do interpretacji, autorytecie specjalistów i sygnaturze autorskiej - ale tuż pod powierzchnią, nawet nie w jakiejś tajemnej głębi, porusza się wśród rzeczy pierwszych i ostatecznych, w zawrotnych przestrzeniach „Luriańskiego mitu",gdzie Bóg-artysta rozpisuje swoje dzieło, a następnie odchodzi, pozostawiając tylko własny podpis: Yes, yes, rytmiczną podwojoną afirmację, która pulsuje w tekście świata jak bicie serca, jego sekretny krwiobieg, życiodajny śmiech, oui-rire. Yes, I said Yes, ostatnie słowa monologu Molly Bloom, potwierdzone raz jeszcze odautorską sygnaturą - Yes, yes - są dla Derridy znakiem, że dzieło Joyce’a / dzieło Boga (Joyce’a jako Boga wśród artystów, Boga jako

2 W opowieści tej Rabbi Eliezer ben Hyrkanos spiera się ze swymi uczniami na temat interpretacji halachy; ponieważ nie może ich przekonać, z pomocą przychodzi mu sam Bóg, dokonując różnych cudownych interwencji; w końcu jednak wstaje Rabbi Jirmeja i mówi: „Tora została już dana z góry Synaj. Nie zważamy na żaden głos niebieski, albowiem już na górze Synaj zapisałeś w Torze: Wedle większości należy postanawiać": G. Scholem /udaizm. Parę głównych pojęć, przeł. J. Zychowicz, inter esse, Kraków 1991, s. 130-131. Uśmiech „pokonanego" Boga wieńczy tę historię, nadając jej wydźwięk bezdyskusyjnie afirmatywny. Podobna aluzja do cimcum jako aktu, w którym Bóg niejako pokonuje, przezwycięża albo wręcz dekonstruuje sam siebie, pojawia się u Levinasa w kluczowym kontekście separacji: „Nieskończoność, rezygnując z zaborczego uścisku całości, powstaje przez skurczenie, które zostawia miejsce dla bytu oddzielonego", E. Levinas Całość i nieskończoność. Esej o zewnętrzności, przeł. M. Kowalska, PWN, Warszawa 1998, s. 112.

3 J. Derrida Ulysses Gramophone: Hear Say Yes in Joyce, w: A Derrida Reader. Between the Blinds, ed. P. Kamuf, Harvester Wheatsheaf, New York 1991, s. 589 (odtąd jako UG).

\section{http://rcin.org.pl}


Joyce’a wśród bogów) należy czytać jako szczególne ćwiczenie w afirmacji, którego celem jest stworzenie „daru doskonałego”: daru, który odrywa się od swojego twórcy i oddaje się całkowicie do dyspozycji adresata, nie żądając odeń żadnego zwrotu.

Byłby to zatem dar poza ekonomią krążenia darów w stylu opisanym przez Marcela Maussa, którego doskonałość polega na tym, że adresat nawet nie wie, że został obdarowany (co, nota bene, umieszcza się na szczycie uczynków sprawiedliwych wedle listy Mojżesza Majmonidesa: dać tak, by dar był anonimowy, a najlepiej jeszcze nie kłuł w oczy jako darowizna). W przekładzie na język metafizyczny - a esej o Joysie jest modelowym wprost przykładem takiej oscylacji idiomów - ta zasada najwyższej micwy oznaczałaby ze strony nas, obdarowanych, zgodę na ateizm: na odebranie tego, co jest, jako po prostu istniejącego, bez przyczyny i bez celu, w pełnej, jakby rzekł Nietzsche, „niewinności stawania się”, bez winy i grzechu, bez poczucia zadłużenia wobec istoty, dzięki samopoświęceniu której istniejemy. Wieloletni spór Derridy z Heglem, potem odtworzony w jego debacie z Marionem, a raz jeszcze powtórzony w dyskusji z Nancym, krąży uparcie wokół jednego motywu, w którym Derrida zaznacza swoją żydowską różnicę wobec tych dwóch myślicieli chrześcijańskich (nawet jeśli ich rozumienie chrześcijaństwa jest bardzo odmienne): podczas gdy w heglowskiej parafrazie kenozy świat powstaje dzięki Entäusserung, czyli uzewnętrznieniu/samoofiarowaniu Boga-Idei w jego pierwotnej postaci, a w ten sposób powstały świat żyje w poczuciu winy i zadłużenia, „nieskończonej żałoby w tym, co skończone"4 - dar doskonały nie wytwarza w obdarowanym potrzeby odkupienia. Więcej jeszcze: wolno o nim prawie-że-zapomnieć, wolno oddać się niemal ateistycznej swobodzie niepamiętania i nieopłakiwania, ponieważ "na początku" nie wydarzyło się w istocie nic skandalicznego, żadna katastrofa i żaden skandalon (jak święty Paweł nazywa akt kenozy, czyli wcielenia). Przeciwnie, stworzenie świata skończonego, który zakończył Nieskończone, oddając całe istnienie na poczet skończoności, „było dobre”: ki tov, Yes, yes.

Cimcum bowiem, mimo pewnych powierzchownych podobieństw, nie jest tym samym, co kenosis. Bóg nie umiera w swej suwerennej postaci, a już z pewnością nie umiera „dla nas": nie czyni ze swego bytu doskonałego ofiary na rzecz nas, grzeszników zaludniających świat upadły, zadłużony w boskim

4 Por. G.W.F. Hegel Faith and Knowledge, trans. W. Cerf, H.S. Harris, SUNY Press, Albany 1977, S. 190.

\section{http://rcin.org.pl}


samopoświęceniu. Przeciwnie, sam jeszcze-nie-istniejący, sam dopiero „poszukujący bytu” (jak Boehme, już poddany wpływowi Lurii, nazywa ową pierwotną nicość: sein-suchende) wywołuje świat, o którym dopiero można w ogóle powiedzieć, że istnieje. W tej wersji „mitu Luriańskiego”, którą spotykamy u Derridy, Bóg sam okazuje się najbardziej zagorzałym rzecznikiem bytu skończonego. U podstaw każdej późniejszej negacji, która do owej skończoności się dołącza, tkwi źródłowa afirmacja, ponieważ to, co skończone, jest dobre i jako takie stanowi pierwotną pozytywność: „Negatywność może i musi się pojawić, ale nawet jeśli całkiem przejmie władzę, to pierwotne tak nie może już zostać wymazane" (UG, 593). Skończone nie jest więc rezultatem negacji bytu nieskończonego, nie jest efektem ubocznym upadku i odpadania od życiodajnego fons entis, nie jest odpadem procesu emanacji, lecz tym, co od początku zamierzone: faktem pierwotnym. Jeśli coś jest lepsze niż nic, to skończony Świat jest lepszy od nieskończonego Boga ${ }^{5}$.

\section{Nowoczesna praca nad Luriańskim mitem: od Spinozy do Derridy}

Metafizyczno-kabalistyczne intuicje Derridy mogą jednak wydawać się bardzo odległe od samych początków „mitu Luriańskiego”: między samym Izaakiem Lurią, wielkim mistrzem żydowskiej gnozy, który był tak głębokim pesymistą ontologicznym, tak głęboko nieufnym wobec materii, że nie pozostawił żadnej pisemnej spuścizny, a Derridą, entuzjastą pisma w całej jego

5 To właśnie cimcum mając na myśli - dar doskonały, wyzuty z ofiarnicznego kontekstu - Derrida pisze o Heglowskiej Entäusserung, zarzucając Heglowi zbyt mocne zakorzenienie w koncepcji chrześcijańskiej kenosis (które słowo to, nota bene, w niemczyźnie Lutra oznacza): „A może tak: dar, poświęcenie, całopalenie, holokaust - wszystko to oddaje się we władanie ontologii [...] Bez tego holokaustu nie rozpocząłby się dialektyczny ruch bytu i Historii [...] Najwcześniej, zanim jeszcze pojawił się czas, doszło do eruptywnego wydarzenia w formie daru [...] Jednak ten dar mógł zostać pomyślany tylko jako samoofiarowanie - taki bowiem jest aksjomat rozumu spekulatywnego". J. Derrida Glas, trans. J.P. Leavey, R. Rand, Nebraska University Press, Lincoln-London 1986, s. 241-2 (odtąd jako G). Także w Pasjach, ostatnie enigmatyczne zdanie eseju - „tym, co wedle mnie pozostaje, to absolutna samotność pasji bez męczeństwa” - sugeruje inny rodzaj kryptoteologicznego śladu: nie tragiczno-kenotyczną Pasję Chrystusa, pozostającą jako zadra w martyrologicznej pamięci, lecz bardziej otwartą i radosną "pasję transcendencji" (w obu znaczeniach dopełniacza: subiektywnym i obiektywnym), która budzi się w nas "bez powodu" (ohne warum, jak mawiał analizowany przez Derridę w sąsiednim eseju Anioł Ślązak), a nie z obowiązku wywołanego poczuciem winy: J. Derrida On The Name, ed. T. Dutoit, trans. J.P. Leavey (Saufle nom), Stanford University Press, Stanford 1995, s. 31 (odtąd jako ON).

\section{http://rcin.org.pl}


materialności, rozciąga się przepaść, którą przekroczyć mogła tylko wytężona nowoczesna „praca nad mitem"6 . Ta wytężona praca, w której uczestniczą nie tylko sami kabaliści, ale i ogromna część nowożytnej filozofii - od Spinozy, przez Hegla, po Scholema, Benjamina i Levinasa - polega na przełamywaniu klątwy gnozy negatywnej, jaka spoczywa na Luriańskiej kabale. Praca ta, dostosowując się do nowego klimatu modernitas, znacznie bardziej sprzyjającego saeculum, czyli „światowości”, bierze z Lurii podstawowy schemat - sekwencję kontrakcji Boga oraz rozbicia naczyń - ale odwraca negatywny afekt, jaki temu opisowi towarzyszy. Podczas bowiem gdy w najbardziej tradycyjnej i przednowoczesnej wersji przeważa mroczna wizja Boga wycofującego się w głąb siebie w gniewie oraz upadku stworzenia opuszczonego przez Stwórcę, które odtąd męczy się w nihilistycznym piekle skończoności, modernizacja mitu Luriańskiego akcentuje pozytywny kierunek metafizycznych zmian, wychodząc z założenia - z początku cichego, a stopniowo coraz bardziej ujawnianego - że cała ta sekwencja ma swój głęboki sens: nie tylko nie znamionuje katastrofy, ale przeciwnie, wskazuje na właściwą orientację zdarzeń, które wprawdzie nie dojrzały jeszcze do doskonałości, ale zmierzają w dobrym kierunku ${ }^{8}$. I gdy tradycyjna wizja negatywna wiąże ideę deus absconditus, Boga Ukrytego, z grozą niezbadanych boskich wyroków i kapryśnej

6 Pojęcie to przejmuję od Hansa Blumenberga Work on Myth, trans. R.M. Wallace, MIT Press, Cambridge, MA 1985.

7 Wizja ta utrzymuje się także w czasach nowożytnych, zawsze służąc za kanwę do subwersywnej krytyki nowoczesności. Najsilniej pojawia się ona u bezpośredniego ucznia Lurii, Izraela Saruka; potem podtrzyma ją Moshe Chaim Luzzatto, z kolei uczeń włoskiej szkoły Saruka, nazywając cimcum wprost kosmicznym kataklizmem; podobnie uczyni Nachman z Bracławia, mistrz Franza Kafki; Walter Benjamin, nazywając stworzenie "permanentną katastrofą", a także, najbardziej współcześnie, Edmond Jabès. Cień Luriańskiej kabały jako gnozy negatywnej, opisującej stworzenie świata w kategoriach powszechnego wygnania wszystkich rzeczy, spocznie także na filozofii nieżydowskiej, ale czerpiącej z kabalistycznego dziedzictwa, do której zaliczyć można: Jacoba Böhme, Schellinga, a poprzez tego ostatniego także późnego Heideggera, którego termin Abzug des Seins, opisujący proces Seinsverlassenheit, czyli "opuszczania bytów przez bycie", zawiera złowieszczą nihilistyczną konotację. Na temat kariery cimcum w myśli nowożytnej, por. znakomite kompendium Ch. Schulte Zimzum. Gott und Weltursprung (Suhrkamp, Frankfurt am Main 2014) O meandrach gnozy negatywnej u Benjamina, por. znakomite dzieło A. Lipszyca Sprawiedliwość na końcu języka. Czytanie Waltera Benjamina (Universitas, Kraków 2013). Z kolei o Jabèsie i jego wizji „żydowskiej nowoczesności” świetnie pisze Przemysław Tacik w książce Wolność świateł. Edmond Jabès i żydowska filozofia nowoczesności (Austeria, Kraków 2014).

8 Zgodnie z etymologią słowa sens, które wywodzi się właśnie od orientacji, kierunku, poczucia celowości ruchu. 
suwerenności, ten nowy obraz modyfikuje także i to pojęcie: Bóg chowa się nie po to, by ukryć przed światem swoją niepojętą istotę, lecz po to, by dać światu ontologiczne pierwszeństwo.

$\mathrm{Na}$ tę nowoczesną pracę nad Luriańskim mitem składają się cztery etapy. Pierwszy wiąże się z modyfikacją kabalistycznego schematu emanacji, jaka po raz pierwszy pojawia się u Spinozy. Spinoza istotnie może uchodzić za prekursora nowoczesnej żydowskiej kryptoteolog i i, w której Bóg ukrywa się za Światem, by oddać mu ontologiczny priorytet. Świetnie uchwycił to Leo Strauss w swoim niezwykle czujnym komentarzu do Spinozjańskiej krytyki religii, gdzie przedstawia on Spinozę jako prekursora prawdziwie nowoczesnego rozumienia słowa "progres" - postępu dynamicznego, otwartego, nieteleologicznego, jedynie zorientowanego na przyszłość, w przekonaniu, że nie ma "sensu" wracać do niczego, co było przedtem. Rewolucja, jaka odbywa się w pismach Spinozy, polega więc na radykalnej zmianie retrospektywnej orientacji całej tradycyjnej metafizyki. Spinoza podpowiada, że lepiej brnąć w dzieło stworzenia niż próbować zawrócić je do zaprzeszłej boskiej pleromy:

Jego spekulacja przypomina schemat neoplatoński. Pojmuje on istnienie wszystkich rzeczy jako wychodzące od jednego źródła, choć niekoniecznie przez to źródło stworzone; Jedno jest wyłącznie podstawą wielości. Jednocześnie jednak Spinoza nie postrzega tego procesu jako upadku albo zepsucia, a raczej jako wznoszenie się i rozwój: tu następstwo okazuje się wyższe i lepsze od źródła [...] Spinoza jest więc prekursorem wszystkich tych systemów filozoficznych, które utożsamią proces z progresem: Bóg sam nie jest ens perfectissimum. ${ }^{9}$

Zmiana metafizycznej orientacji pociąga za sobą kolejną pozytywną intuicję, której rzecznikiem okazuje się Gershom Scholem. Boskie cimcum, odczytane na nowoczesny sposób, modyfikuje doktrynę neoplatońską jeszcze głębiej. Przecinając łańcuch emanacji - wciąż jeszcze zbyt spójny u Spinozy, a tym samym stawiający pod znakiem zapytania status pojedynczych modi, ich wątpliwą separację i indywiduację - „stworzeniem nicości”, Bóg nie tylko udziela swojego bytu światu w formie niezagrożonego i bezwarunkowego daru, ale także go wyzwala:

9 L. Strauss Spinoza's Critique of Religion, University of Chicago Press, Chicago 1997, s. 16.

\section{http://rcin.org.pl}


Stworzenie z niczego, z próżni, nie mogło być niczym innym, jak tylko stworzeniem próżni, a więc samej tylko możliwości pomyślenia czegoś innego, co nie byłoby Bogiem. Bez tego aktu samoograniczenia byłby bowiem tylko sam Bóg - i nic poza tym. Byt, który nie byłby Bogiem, mógł stać się możliwy i wyłonić się tylko dzięki tego rodzaju kontrakcji, paradoksalnego wycofania się Boga w siebie. Ustanawiając negatywny czynnik w sobie, Bóg wyzwala stworzenie. ${ }^{10}$

Scholem wciąż jeszcze nazywa cimcum aktem boskiej autonegacji - ustanowieniem czynnika negatywnego w Bogu - co wikła wątek Luriański w asocjacje z chrześcijańską kenozą i „śmiercią Boga” (które, historycznie rzecz biorąc, są z pewnością usprawiedliwione). Nowoczesna praca nad Luriańskim mitem jednak postępuje uparcie w kierunku przeciwnym, reinterpretując go w taki sposób, by wyeliminować motyw zadłużenia, w jaką wikła świat chrześcijańska idea samoofiarniczej stwórczej kenozy. Na tym etapie pojawia się wizja immanencji bezwarunkowej - jak u Hansa Jonasa, w jego bardzo już współczesnym przepowiedzeniu kabalistycznej spekulacji. Jonas podkreśla jednak, że immanencji bezwarunkowej nie należy mylić z immanencją panteistyczną, ponieważ panteizm jest statyczny, natomiast Luriańska koncepcja jest m e s ja ń s k a, a więc zakłada, że w świecie jest jeszcze coś do zrobienia; że transcendencja, która wymazuje siebie ze świata, pozostawia w nim pewien ślad, będący jednocześnie źródłem naszych podstawowych intuicji normatywnych i sensotwórczych:

Na początku, z nieznanych nam powodów, podstawa bytu, albo Bóg (das Göttliche), postanowiła wydać siebie na ryzyko i los zróżnicowanego stawania się. I uczyniła to w całości: rozpoczynając przygodę czasu i przestrzeni, boskość nie zachowała nic dla siebie. Żadna jej nieskażona i nieposzkodowana część nie pozostała, by kierować światem, prostować jego losy i dostarczać gwarancji, że w końcu dotrze on do swego przeznaczenia. Nasz nowożytny temperament upiera się przy tak pojętej bezwarunkowej immanencji. Na tym polega jego odwaga, rozpacz, albo po prostu gorzka uczciwość, zdeterminowana, by nasze bycie-w-świecie potraktować na poważnie: by widzieć świat jako pozostawiony sam sobie, rządzony logii żydowskiej w naszych czasach, w: Żydzi i Niemcy, Żydzi i Niemcy. Eseje, listy, rozmowa, przeł. M. Zawanowska, A. Lipszyc, Pogranicze, Sejny 2010, s. 343.

\section{http://rcin.org.pl}


prawami wolnymi od cudownych ingerencji, zaś konieczność przynależenia doń nie zmiękczoną przez żadną pozaziemską opatrzność. Nasz mit postuluje to samo wobec Boga i jego obecności w świecie. Nie chodzi tu bynajmniej o panteistyczną immanencję: gdyby Bóg i świat były po prostu tym samym, świat w każdej chwili reprezentowałby boską pełnię, a Bóg nie miałby wówczas nic do wygrania ani przegrania. Po to, by świat mógł zaistnieć, Bóg wyrzekł się swojego bytu i swej boskości - po to jednak, by je odzyskać u krańca odysei czasu, w której wszystko waży się na szalach losu i nieprzewidywalności temporalnego doświadczenia: odzyskać je przemienione, być może nawet zniekształcone. Porzucając własnowolnie swą boską integralność na rzecz nieuprzedzonego niczym stawania się, Bóg otworzył się tym samym na nieskończone możliwości, które byt kosmiczny oferuje na swych własnych warunkach: Bóg, wymazując siebie ze świata, powierzył swą sprawę kruchemu i niepewnemu "być może"."1

Wydając stawanie się Boga w immanencji nominalistycznemu twardemu prawu bytu skończonego - bez cudów opatrzności i bez przedustawnego ładu uniwersaliów - Jonas po raz kolejny przesuwa barierę pozytywnej relektury Luriańskiego mitu: samo „rozbicie naczyń”, ten teozoficzny odpowiednik kryzysu nominalistycznego, przestaje być katastrofą, a nabiera charakteru katartycznego, na wzór, jak to ujmuje Scholem, „wstrząsów przedporodowych". Ostatnia zapora oddzielająca platoński byt wieczny od temporalnego stawania się,jego losu i nieprzewidywalności, pada, by mógł zaistnieć osobny ziemski czas: czas, który z istoty swojej - jak za chwilę zobaczymy - musi być out of joint. Nowoczesny kosmos wypadły z kolein to zatem byt powszechnego wygnania, który wyłonił się po rozbiciu boskich naczyń. Obie metafory, pozornie tylko pejoratywne, mówią dokładnie o tym samym: o narodzinach Świata.

\section{Afirmatywny antynomizm}

To jednak nie koniec tej pracy przekuwającej straszliwą baśń o kosmicznej katastrofie, gdzie zło tkwi już bereszit, w samym początku, na opowieść opatrzoną - jeśli już nie happy endem (tego wiedzieć nie możemy), to przynajmniej

11 H. Jonas Mortality and Morality. A Search for the Good after Auschwitz, trans. L. Vogel, Nortwestern University Press, Evanston 1996, s. 134.

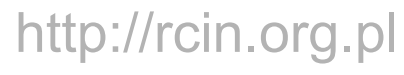


bardziej obiecującym incipitem. Za kolejną modyfikację mitu Luriańskiego odpowiada sam Derrida, który dokonuje jeszcze jednej, niezwykle kunsztownej przewrotki, po raz kolejny świadczącej o tym, że w przypadku autora Widm Marksa mamy do czynienia z najwyższą szkołą mesjańskiej jazdy. Widmo, ostatnie wcielenie ruach - owego Ducha, od którego rozpoczyna się „odyseja czasu" po to, by się na nim nie zakończyć; Ducha, który jest czystym żywiołem p o c zy n a n i a, a więc stawania się in ny $\mathrm{m}^{12}$ - wywodzi się wprost z żydowskiej gnozy apokaliptycznej, której ostatnim przedstawicielem w myśli XX-wiecznej był Jacob Taubes, twórca Zachodniej eschatologii. Nie ma już jednak w sobie nic z tego "ducha zemsty", który tradycyjnie ożywiał sceny apokalipsy - jednocześnie objawienia i zniszczenia - czyli „zdarcia zasłony”, wraz z którą zdziera się również cały byt.

Taubes, wciąż jeszcze wrośnięty w formułę gnozy apokaliptycznej, nie może wyobrazić sobie Boga ukrytego inaczej, jak tylko mściwą "przeciwzasadę świata" (Gegenprinzip der Welt), która czai się w zaświatowym ukryciu tylko po to, by w końcu uderzyć i położyć kres upadłej ziemskiej historii. To właśnie egzorcyzmowaniu tego aspektu mściwości poświęcona jest pierwsza część Widm Marksa, która idzie zupełnie osobnym tropem od analogicznej Nietzscheańskiej krytyki „ducha zemsty” jako tak zwanej „żydowskiej antytezy”. Nie chodzi tu bowiem o proste utożsamienie zemsty z negacją, co wieść może tylko do bezwarunkowej amor fati i powszechnego Ja-Sagen, a więc potakiwania światu nawet wtedy, gdy dzieje się w nim jawna niesprawiedliwość. Raczej chodzi o to, by negację oderwać od mściwego schematu eschatologicznego, w którym Bóg Ukryty staje się synonimem końca świata, i uczynić ją sz tu ką w łonie wszystko poprzedzającej i poczynającej pra-afirmacji: sztuką, czyli dekonstrukcją. Nie w tym rzecz zatem, by negacja miała zniknąć; rozpłynąć się w wielkodusznym umiłowaniu losu, która "afirmująco afirmuje" wszystko, co jest, dokładnie takim, jakim jest. Wówczas bowiem usunęlibyśmy sobie spod nóg warunek możliwości wszelkiej krytyki - pytania, protestu, roszczenia - co wycofałoby nas znów do złej metafizyki daru, gdzie bytowi, niczym darowanemu koniowi, nie wypada zaglądać w zęby, a jedyną reakcją na świat może być tylko wdzięczność i poczucie zadłużenia.

12 W eseju O duchu, napisanym na marginesie "afery Heideggera” rozpętanej przez Vittorio Fariasa, Derrida nazywa Ducha, der Geist, „najbardziej porannym z Frühe”, bereszit, prawczesnością będącą tym samym, co zdolność początkowania: „tym, co właściwe duchowi, jest ta samopobudzająca się spontaniczność, która nie potrzebuje żadnej zewnętrzności, żeby zająć się ogniem lub żeby dać ogień, żeby ekstatycznie przejść poza siebie". J. Derrida O duchu. Heidegger i to pytanie, przeł. A. Brzezicka, PWN, Warszawa 2014. 
Negatywność jest więc niezbędnie konieczna, by Hiob, ta arcyludzka figura, mógł przerwać milczenie i wypowiedzieć pod adresem bytu swoje wątpliwości i roszczenia. Sprawiedliwość z kolei musi mieć w sobie ładunek negatywności - je s z c z e - n i e - by ć, zawierać się w nieobecności, nieurzeczywistnieniu, w poczuciu, że „czegoś brakuje” - by nie roztopić się w tym, co już jest, które, właśnie dlatego, że już zaistniało, ma za sobą wielką siłę perswazji, zwaną za Adornem „potęgą adaptacji”. Jednocześnie jednak negatywność ta nie może przejąć wszystkiego: nie może rozrastać się bez granic, jak właśnie w wizji apokaliptycznej, gdzie potędze bytu już zaistniałego przeciwstawia się nagle ujawniona omnipotencja Boga jako p r z e c i w $\mathrm{z}$ a s a d y. Derridiańskie rozważania o Hamlecie mają nam więc uświadomić, że sprawiedliwość nie jest zemstą, zaś widmo Boga Ukrytego krążące nad światem nie jest mściwym Duchem Ojca, który w imię swojego rozumienia sprawiedliwości jako zadośćuczynienia poświęciłby cały świat: pereat mundus sed fiat iustitia ${ }^{13}$.

Derrida odrzuca system sprawiedliwości oparty na długu, zadośćuczynieniu i retrybucji, demaskując go - za Benjaminem rzecz jasna - jako system mityczny, zanurzony w archaicznej pogańskiej mentalności, dla której prawo to nade wszystko prawo zemsty, karzącej każdy przejaw hybris (czyli w istocie każdy przejaw życia). Negacja, jaką żywi się ideał sprawiedliwości, nie może opierać się na zadośćuczynieniu, które jest tak naprawdę o d c zy n i e n i e m, a więc unicestwieniem złego stanu rzeczy; jeśli bowiem uogólnić tę zasadę, a tak właśnie czyni wyobraźnia apokaliptyczna (bardziej w istocie pogańska niż mesjańska), to szał odczyniania zaczyna zwracać się przeciw stanowi rzeczy jako takiemu, a więc przeciw całemu światu. Na końcu tego procesu czyha więc pułapka gnozy negatywnej, potępiającej byt hurtowo w heglowskiej „furii zanikania”: lepiej, by niczego nie było; tragiczna mądrość me phynai [obym się nie narodził], Bartleby'ego I'd prefer not to...

Szekspirowska historia księcia Hamleta służy Derridzie za kanwę relacji między żywą jednostką i nie-umarłym widmem, która jego zdaniem nie jest relacją przygodną, lecz konstytutywną dla ludzkiej podmiotowości. „W naszych głowach straszy", powtarza Derrida za Marksem, lecz, w przeciwieństwie do tego ostatniego, zaleca "gościnność wobec duchów" - możliwą

Derrida wielokrotnie deklarował swą niechęć do apokalipsy, protestując przeciw łatwemu utożsamianiu jej z mesjańskością, której zadaniem jest raczej przemieniać byt, a nie go niszczyć. Por. zwłaszcza J. Derrida No Apocalypse, Not Now (Full Speed Ahead, Seven Missiles, Seven Missives), trans. C. Porter, P. Lewis, "Diacritics" Summer 1984 vol. 14 (2).

\section{http://rcin.org.pl}


jednak tylko wówczas, gdy te przestaną nas s tr a s z y ć. Dlatego też zaczyna od dekonstrukcji relacji między Hamletem żywym i Hamletem widmowym, w wyniku której okazuje się, że rezygnacja Hamleta z własnego życia na rzecz żądania zgłaszanego przez ojcowskie widmo, kończy się źle dla samej sprawiedliwości, która ustępuje surowemu prawu retrybucji: ojcowskie widmo, domagając się sprawiedliwości, uzyskuje jedynie zemstę, domykając historię w kręgu „mitycznej ekonomii”. Analizując Szekspirowską sentencję - the time is out of joint - Derrida przedstawia Hamleta jako podmiot proto-marksowski, który zapowiada przesłanie Manifestu komunistycznego, ale też jako podmiot nowoczesnej metafizyki, dla której istnienie świata skończonego, pogrążonego w czasie, nie stanowi już skandalu wołającego o pomstę do nieba. Derridiański Hamlet wcale nie chce wtłaczać świata na powrót w utarte koleiny, co oznacza także stare szlaki grecko-chrześcijańskiej metafizyki z jej „teologicznym absolutyzmem", spychającym materialny byt świata na margines. Przeciwnie, pragnie podtrzymać jego „wykolejenie” - gdzie „wszystko, co stałe, wyparowuje" - czując, że to ono właśnie okazuje się podwójną szansą: na sprawiedliwość, czyli wymknięcie się prawu zemsty/retrybucji/powrotu -

Hamlet nie przeklina wcale zepsucia swego wieku. Nade wszystko przeklina niesprawiedliwy efekt tego wykolejenia; przeklina los, który predestynuje go do ponownego uporządkowania świata, do przywrócenia go prawu. Przeklina więc swoją misję - misję naprawy czasu [...] Jeśli więc prawo wywodzi się z zemsty, jak w swych żalach sugeruje Hamlet przed Nietzschem, Heideggerem, a także Benjaminem - to czy nie staje się wówczas możliwa tęsknota za dniem [...] dniem quasi-mesjańskim, na trwałe wyjętym spod losowej konieczności zemsty? ${ }^{14}$

Ten quasi-mesjański dzień nie jest jednak dniem końca świata: przeciwnie, stanowi we wnątruś wi a tow y ideał sprawiedliwości, dzięki któremu historia będzie mogła wymknąć się spod panowania mściwego prawa retrybucji. Czy oznacza to także wolność od „nawiedzenia”? Tak, jeśli nawiedzanie jest „straszeniem” w stylu starego Hamleta; nie, jeśli już nie budzi lęku. Kiedy więc Derrida zaleca, by „odczynić lęk przed duchami wybuchem śmiechu" (SM,47), to nie znaczy to, że odrzuca on wszelkie spektralne

14 J. Derrida Specters of Marx. The State of the Debt, the Work of Mourning, and the New International, trans. P. Kamuf, intr. B. Magnus, S. Cullenberg, Routledge, London 1994, S. 20-21 (odtąd jako $\mathrm{SM})$.

\section{http://rcin.org.pl}


uwiedzenie. Ten śmiech znaczy tu co innego: to odpowiedź na inny, pierwotniejszy śmiech, śmiech samego Widma, jego pra-afirmatywne oui-rire. To dzięki słyszeniu tego źródłowego, „prawczesnego” Ja-lachen Widmo przestaje stras zyć - domagać się zemsty, metafizycznego odczynienia bytu, powrotu do doskonałej zaprzeszłości, do pleromy sprzed kosmicznej katastrofy, odkupienia grzechu zaistnienia, naprawy czasu - a zaczyna n a p r o w a d z a ć, co przecież także jest rolą duchów-przewodników. Zaczyna więc o r i e n t o w a ć: „nie tylko na przeszłość, ale także na przyszłość” (SM, 181). Orientacja ta - zgodnie z etymologią znacząca tyle co "nadawanie sensu/ kierunku” - ma gwarantować, że „słaba siła mesjaniczna”, o jakiej wspomina przy okazji Benjamina, nie wyczerpie się w zobowiązaniach wobec przeszłości, grożących nawrotem „,koła zemsty”, lecz popchnie bryłę świata, już od początku ruszonego z posad, do przodu; nawet jeśli znaczenie tego p r o g r e s u pozostaje widmowo mgliste ${ }^{15}$.

Cała ta analiza służy Derridzie do tego, by móc rozwiązać problem radykalnej sprawiedliwości: tak, by pozostała $\mathrm{r}$ a d y k aln a, a jednocześnie nie pragnęła zniszczenia całego świata w stylu Goetheańskiego Mefista, który nonszalancko obwieszcza: „albowiem wszystko, co powstaje / do wytępienia tylko się nadaje". Jak zatem sprawić, by negacja mogła odegrać w bycie rolę prawdziwie „krytycznej krytyki” (by pozostać w idiomie Marksa), zarazem nie przejmując nad bytem władzy w postaci apokaliptycznej zemsty? Jak to urządzić, by widmo krążące nad światem sprzyjało jego dążeniu do sprawiedliwości, jednocześnie nie podważając jego prawa do bytu? Kluczem do tego subtelnego rozwiązania jest właśnie Derridiańska idea obiecującego incipitu, od którego ta opowieść się zaczyna: p r a - a fi r m a c j i, wobec której wszystkie negacje okazują się późniejsze i wtórne, ale która ich bynajmniej nie unieważnia. Tę ostatnią odsłonę pracy nad Luriańskim mitem można by więc określić, z pozoru paradoksalnie, jako a nty no mizm a firmaty w ny: świat, byt, rzeczywistość stworzona, jakkolwiek opiszemy dziedzinę bytu skończonego, ma zielone światło na metafizycznym planie. Czerwone światła stopu mają zaś zapalać się nie wobec bytu w ogóle, lecz tylko w tych

15 Samemu Marksowi natomiast zarzuca nadmierne przywiązanie do tego, co jest tu i teraz, kosztem mglistych widm, do których zalicza on także ducha mesjańskiej obietnicy, zamieszkałego w marksowskim „widmie komunizmu”: "Ta niechęć do duchów, ta przerażona wrogość, która odpędza strach wybuchem śmiechu, przybliża Marksa do jego przeciwników. On także będzie chciał sprzysiąc się [conjurer] przeciw duchom, przeciw temu, co nie jest ani życiem ani śmiercią [...] Będzie chciał odpędzić duchy w takim samym geście jak konspiratorzy starej Europy, którym Manifest wydaje wojnę" (SM, 47). 
wszystkich konkretnych i zawsze pojedynczych „stanach rzeczy”, w które wkracza dekonstrukcja, wiedziona we wnątr z światowy m ideałem sprawiedliwości.

\section{Zakhor: w przyszłości pamiętaj o przyszłości}

Dar doskonały, choć nie zadłuża i nie obciąża obdarowanego „pamięcią Pasji”16, nie jest jednak całkiem „niepamiętny”: on także ma swój subtelny sposób przypominania o sobie, tyle że, jak to właśnie wywiedliśmy, przypominania zorientowanego na przyszłość. W ten oto sposób definiuje Derrida fundamentalny imperatyw judaizmu - zakhor! - w Goraczce archiwum: „W przyszłości - pamiętaj o przyszłości"17. Także w tekście o Joysie pojawia się sugestia innej pamięci, która wiąże się nie z pierwotną negacją (śmiercią/autodekonstrukcją Boga), lecz z pierwotną afirmacją. Ta pra-afirmacja, która wyprzedza wszelką negatywność - a wraz z nią "stan zadłużenia i pracę żałoby” (jak głosi podtytuł Widm Marksa) - opiera się na ciągłości obietnicy wychylającej się ku temu, co jeszcze nie istnieje, ale co jest niczym „wspomnienie z przyszłości":

Tak może wypowiedzieć samo siebie tylko wtedy, kiedy obieca sobie swoją własną pamięć. Afirmacja Tak jest zarazem afirmacją pamięci [...] Afirmacja domaga się a priori konfirmacji, powtórzenia, zachowania, pamięci owego Tak [...] Tak z konieczności powierza się pamięci innego, Tak wypowiadanym przez innego i jego innego Tak. (UG, 576; 585; 596)

Pra-afirmacja, która jest właściwym kontekstem cimcum, wytwarza więc rodzaj więzi łączącej byty, jednocześnie jednak nie gwałcąc ich separacji i odmienności; podczas gdy wina zadłuża i przymusza do odpłaty w ramach ekonomii odkupienia, skuwając wszystko w wielki łańcuch bytów, the great chain ofbeings, tu nie pojawia się element przymusu. Ani nawet element perswazji: raczej przyłączenia się do rytmu - yes, yes - który już sugeruje samo powtórzenie, niemal „quasi-mechaniczne”. To tu być może należy upatrywać rozwiązania dość enigmatycznej idei z eseju Wiara i wiedza, gdzie więź religijna

16 Por. J. Derrida Wiara i wiedza. Dwa źródła "religii" w obrębie samego rozumu, przeł. P. Mrówczyński, w: J. Derrida, G. Vattimo i in., Religia, Aletheia, Warszawa 1999, s. 64.

17 J. Derrida Archive Fever. A Freudian Impression, trans. E. Prenowitz, Chicago University Press, Chicago 1996, s. 76. 
(re-ligere) okazuje się rodzajem mechanizmu uruchamiającego się prawie że a piori: przed wiedzą, przed wolą, a nawet przed samą wiarą. Mechanizmu, który wiąże i przyłącza, zanim wyłoni się namysł i decyzja, pociąga w wir potężnego Yes, yes - podobnie jak Nietzsche wyobrażał sobie wspólnotę "gwiazd tańczących," pogrążonych w ekstatycznym Ja-sagen. Mechanizm ten jednak jest obosieczny: jednocześnie „starszy niż wszelka wiedza” (UG, 590), wydaje się on na ryzyko alienacji, bezmyślnego potakiwania i jedynie odruchowego podrygiwania w rytm tej kosmicznej wibracji, jaką jest incipit/sygnatura Yes, yes:

Nie możemy oddzielić od siebie tych bliźniaczych „tak", a jednak pozostają one zupełnie odmienne [...] Takie podwojenie wynika nie tyle z samej sygnatury Ulissesa, ile z wibracji tego wydarzenia, które odnosi sukces tylko poprzez prośbę/pytanie/zaproszenie. (UG, 597)

Ta prośba/pytanie/zaproszenie niesie ze sobą niebezpieczeństwo, które jest nieuchronnym rewersem jego „sukcesu”: wszystko może pójść nie tak, ponieważ nie ma żadnych gwarancji, że wici rozpuszczone po całym wszechświecie dotrą do adresata $\mathrm{w}$ formie nie będącej tylko głuchym echem pierwszego słowa (jak w Kafkowskiej Wiadomości od cesarza, która dociera nie tylko za późno, ale i zdeformowana nie do poznania). Yes, yes nie wiąże absolutnie, nie spaja, nie przymusza, nie daje gwarancji zwrotu. Nie ma tu miejsca na heglowską "chytrość rozumu”, która, czy chcemy tego, czy nie, odzyska "swoje" po całym biegu historii i odtworzy boskość w postaci Wiedzy Absolutnej. Nie ma też miejsca na odkupienie długu, jakim byłaby restytucja boskiej pełni po tym, jak poddała się samoofiarniczemu „uzewnętrznieniu”. W akcie cimcum Bóg „wysyła” siebie w świat [s'envoyer] na sposób, który nie zakłada zwrotu do nadawcy: „koło się nie zamyka” (UG, 595). Nie ma zawłaszczenia - jest tylko z a p r o s z e n i e (kolejne ważne słowo w kryptoteologicznym almanachu Derridy, analizowane szczegółowo przy wielu innych okazjach).

Ryzyko, że dzieło stworzenia zejdzie na manowce, jest więc wpisane w ideę cimcum jako daru doskonałego, a więc bezzwrotnego. Świat jest wolny, ponieważ jest prawdziwym in ny m: jest w istocie Eliaszem, którego nie sposób na powrót zawłaszczyć, można go tylko zaprosić do raz zapoczątkowanego przedsięwzięcia. Nigdy nie zdradzając wprost swoich żydowskich inspiracji, Derrida, ten maran doskonały, wczytuje w Joyce'owską „śmiejącą się" sygnaturę Yes, yes Luriański koncept rishum/reshimu [sygnatury/resztki],

\section{http://rcin.org.pl}


która jest tym, co pozostaje po Nieskończonym po tym, jak popełnił on akt cimcum, tym samym afirmując nadejście in ne go. To ona naw i edza potem świat, bynajmniej nie po to, by budzić lęk:

Jednakże eschatologiczny ton tego tako - ś m i e ch u [oui-rire] wydaje się przenikać - choć wolałbym powiedzieć, n a wi ed z a ć - zupełnie inna muzyka, jakby samogłoski zupełnie innej pieśni, radośnie brzuchomówczej. Słyszę ją tak wyraźnie, jako tako-śmiech daru bez zadłużenia; afirmację lekką aż do granic amnezji daru, który jest wydarzeniem pozostawionym samemu sobie [abandonné]. To w klasycznym idiomie nazywa się zwykle „dziełem” zaginioną sygnaturą pozbawioną imienia własnego, która zakreśla krąg możliwego zawłaszczenia tylko po to, by ograniczyć fantazmat własności i dokonać przełomu koniecznego, by mógł nadejść ktoś inny: inny, którego zawsze można nazwać Eliaszem [...] Eliaszem, tym innym. (UG, 589; podkreślenie moje - A.B.-R.)

Prawie zapomnienie, prawie że amnezja - prawie - że - a te i z m a jednak nie do końca. Raczej, jak to ujmuje Derrida w eseju o Aniele Ślązaku i jego wersji opuszczenia/odpuszczenia, czyli Gelassenheit: „zapomnienie bez zapominania" -

Tak czasem pojmuję tradycję Gelassenheit, tej afirmatywnej pogody, która zezwala na bycie bez obojętności i która odpuszcza bez opuszczania, albo też i opuszcza, ale bez zapominania - albo po prostu: zapomina bez zapominania. (ON, 73: podkreślenie moje - A.B.-R.)

Prawdziwe odpuszczenie zatem - dar bez długu - nie polega na zwykłym o p u s z c z e n i u [abandonement] jak to "tradycję Gelassenheit" skłonni są pojmować dziś, za Heideggerem, Agamben i Nancy (za chwilę do tego wrócimy). Podobnie „zapomnienie Boga” - gdzie dopełniacz jest tak subiektywny, jak obiektywny, nie jest tu prostym Nietzscheańskim Oubliez Dieu!, lecz skomplikowanym ruchem pamięci, w którym to najpierw Bóg sam zapomina o sobie, by następnie dać się zapomnieć stworzeniu. To jednak w paradoksalny sposób właśnie o Bogu p a mi ęt a, ponieważ „opuszczając” go, wykonuje posłusznie boski plan (stąd zalecenie Ślązaka: „opuść Boga, który opuszcza samego siebie"). Ukrycie się Boga, jego, jak to ujmuje Derrida, a te ol o gi z a c ja, „odbóstwienie”, nie jest więc manewrem radykalnego ateizmu, który spycha Boga na margines, by wywalczyć miejsce dla

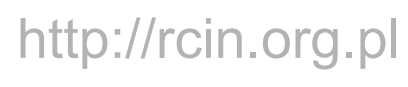


Świata. Sekularyzacja - wyłonienie się nowożytnego saeculum - jest manewrem dokonującym się w łonie religijnego paradygmatu zachodu, równoległym do uformowania się jemu tylko właściwej kryptoteologii. Luriańskiej właśnie.

\section{Ciało i duch; corpus i spectre}

W książce poświęconej filozofii Jean-Luca Nancy'ego, O Dotyku, Derrida raz jeszcze przypuszcza atak na chrześcijańską tragedię krzyża i specyficzny narcyzm wynikający z kenozy:

Pewien rodzaj chrześcijaństwa będzie zawsze dążył do tego, by przejąć dekonstrukcję w jej najbardziej skrajnej, eschatologicznie przegiętej formule, która usiłuje przelicytować stwierdzenie: hoc est enim corpus meum. Takie chrześcijaństwo jeszcze uczyni poświęcenie z własnej autodekonstrukcji. Hej, Markizie de Sade - oto coś dla ciebie! $!^{18}$

Sadyczny aspekt chrześcijaństwa - nawet, a może zwłaszcza takiego, które jest udziałem Nancy'ego - polega na tym, że Bóg umierając, czyli dokonując radykalnej samodekonstrukcji, nie pozwala odejść swojemu stworzeniu i na zawsze czyni je wi n ny m: obciążonym przez zaprzeszły dług i dlatego też niezdolnym do wyrwania się z kręgu przeszłości. Jeśli więc chcemy myśleć pozytywnie o Bogu, który staje się bytem skończonym nakierowanym na przyszłość, musimy wymknąć się pułapce kenozy, która pod płaszczykiem Pawłowego „skandalu” przemyca myśl o kosmicznej katastrofie, i nadać temu aktowi fi n i t y z a c j i formę twórczego otwarcia, poza ekonomią winy i odkupienia. To tu właśnie, jak już dowiedliśmy, wkracza idea cimcum jako nie ofiarniczej i niekatastroficznej autodekonstrukcji Boga:Joyce'owskie podwojone TAK, bez cienia wątpliwości.

Ale w tej filipice Derridy przeciw Nancy'emu chodzi też o coś więcej niż tylko cierpiętnicze asocjacje związane z kenosis: chodzi też o masochistyczny aspekt wcielenia, którego spełnieniem/entelechią okazuje się corpus, martwe ciało; hoc est enim corpus meum, „oto ciało moje”. Tym, co p o z o s t a j e po śmierci Boga, nie jest więc próżnia, lecz miejsce czystej cielesnej ekstensji, jego martwy corpus, „opuszczone” szczątki. Jeśli więc odejście Boga ja ko

18 J. Derrida On Touching - Jean-Luc Nancy, trans. Ch. Irizarry, Stanford University Press, Stanford 2005, s. 60 .

\section{http://rcin.org.pl}


Boga jest darem dla świata, to tylko w charakterze „daru śmierci”, który Nancy (w przeciwieństwie do Derridy i jego znacznie bardziej ironicznego Donner la mort) rozumie całkiem dosłownie:

W taki oto sposób boska chwała ulega podziałowi: Śmierć, Świat, Zgnilizna jako Najwyższa Tajemnica, błoto jako ukształtowanie, ductus miejsc. ${ }^{19}$

Nienazwany Bóg zanika wraz z tą nienazywalną rzeczą [jaką jest śmierć - A. B.-R.]: ginie w n i ej, objawia się w niej jako martwy, nastaje Śmierć we własnej Osobie [...] Bóg przybrał ciało, rozpostarł się i nadał sobie kształt ex limon terrae: $[\ldots]$ z rozciągłości gliny. $(\mathrm{C}, 54,56)$

Jeśli więc, jak twierdzi Nancy, „,chrześcijaństwo jest ateizmem”20 już ze swojej istoty, ponieważ tym, co objawia, jest ciało martwego Boga, to materializm zachodniego myślenia jest prostym wynikiem autodekonstrukcji - albo literalnie, rozkładu - judeochrześcijańskiej religii, która doprowadza siebie, jako religię, do kresu; najpierw powołuje do istnienia bezcielesną transcendencję, a następnie obdarza ją ciałem i nakazuje umrzeć, pozostawiając na koniec tylko czystą kartezjańską res extensa - glinę, wosk, proch, limon terrae. To zatem, co stanowi o specyfice nowożytnego Zachodu, to istotnie przejście od nieskończoności do skończoności, tyle że tu dokonujące się jako upadek do najniższej sfery skończonych ciał opisanych i ograniczonych przez śmierć, jako Benjaminowska „permanentna katastrofa”:

Jeśli, jak sama nazwa sugeruje, Zachód to zapadanie się i upadek, to wówczas ciało jest tym ostatecznym ciężarem, najcięższym balastem zapadającym się wraz z upadkiem. Ciało jest ciężarem [...], niezawodną katastrofa [desastre]: zaćmieniem, zimnym prysznicem ciał niebieskich. Czyż nie po to tylko wymyśliliśmy niebo, aby spadały z niego ciała? $(\mathrm{C}, 7)$

Derridiańska odpowiedź na ten katastroficzny materializm obcesowo wyłożony przez Nancy'ego, ale obecny także w całej linii myślicieli:

19 J.-L. Nancy, Corpus, przeł. M. Kwietniewska, słowo/obraz terytoria, Gdańsk 2002, s. 56 (odtąd jako C).

20 J.-L. Nancy Dis-enclosure. The Deconstruction of Christianity, trans. B. Bergo, Fordham University Press, New York 2008, s. 35 (odtąd jako DC). 
u Deleuze'a, Blanchota i Agambena - jest subtelna. W pewnym sensie Nancy bardzo ułatwia Derridzie votum separatum wobec jego hipermaterialistycznego stanowiska, czyniąc je zależnym od autodekonstrukcji chrześcijaństwa, a więc od ruchu ateizacji wpisanego w samo chrześcijańskie objawienie, kończące „mit Chrystusowy” na śmierci Boga. Sam, jako zwolennik innego „mitu”, nie musi czuć się zobowiązany tym, c o po z o s ta j e po umarłym chrześcijańskim Bogu, i ma prawo wyobrażać sobie „okcydentalizację”, czyli przejście od nieskończoności do skończoności inaczej. W swojej niezwykłej medytacji nad Heglem, która implicytnie konfrontuje heglizm z ezoterycznym dziedzictwem Lurii, Derrida wyobraża je sobie jako przejście od Substancji do Podmiotu:

Światło spowija ciemność, zanim to jeszcze stanie się podmiotem. Ażeby słońce mogło stać się podmiotem, musi najpierw zajść [décline]. Podmiotowość zawsze wytwarza się w ruchu okcydentalizacji [...] Na tym polega początek historii, jako początek tego z a ch o d z e n i a, samo przejście do zachodniej podmiotowości. Ogień staje się „dla siebie” i natychmiast się zatraca. $(G, 239-40)$

W tej wizji nie tyle Zachód zachodzi, czyli upada - jak u Nancy'ego: z nieskończoności światła w mroki rozciągłej pokawałkowanej materii - ile Światło samo zachodzi jako wszechspalające słońce świetlistej substancji [Lichtwesen], by stać się podmiotem; a jako podmiot, być już odtąd tylko łuną na horyzoncie, chowającą się za krawędzią świata, który w ostatnim momencie zapadania się, w ostrym reliefie oświetla. Zatem podczas gdy w „micie” Nancy'ego tym, co pozostaje po jego dopowiedzeniu do końca, jest już tylko „zmierzch” immanencji zapełnionej rozproszonymi martwymi ciałami, już nawet nie Świat, raczej zdezintegrowana nie-całość - tym, co wciąż jeszcze się tli jako niedopowiedziana resztka, to w „micie” Derridy jest widmowe światło Ducha jako „zachodzącego słońca”, które odchodzi w cień, by dać zarys Światu.

\section{Duch opowieści}

Dlaczego jednak w ogóle snujemy te mityczne opowieści, te „baśnie metafizyczne"? Po co Nancy'emu mit chrześcijaństwa doprowadzony do jego logicznego końca: czy nie wystarczyłby sam materializm, wychodzący wprost od faktu istnienia ciał jako factum brutum? I po co Derridzie wciąż niezakończona

\section{http://rcin.org.pl}


praca nad mitem Luriańskim, która dostarcza śladu bezcielesnej boskości w resztkowej postaci widma? ${ }^{21}$

Stanowisko Nancy'ego, będące tu tylko synekdochą bardzo silnej nowożytnej linii filozoficznej zwanej radykalnym materializmem, można opisać terminem wprowadzonym przez Hansa Blumenberga jako antytezę do „pracy nad mitem”: „doprowadzenie mitu do końca”. Nancy traktuje „śmierć Boga” objawioną w chrześcijaństwie z absolutną dosłownością: Bóg odchodzi całkowicie, nie asekuruje się żadnymi „schowkami” (DC, 35) i pozostawia po sobie tylko „szczątki”: martwy corpus rozciągłego uniwersum, który będzie tam odtąd po wieki wieków, po prostu „zajmując miejsce”22. Ostateczne wykończenie mitu judeochrześcijańskiego służy temu, by ten już nigdy nie powrócił i by zachodnia nowoczesność rozpoznała w sobie epokę nieodwracalnej „śmierci Boga”, której nie sposób odczynić oczekiwaniem na rezurekcję. Inaczej niż Hegel zatem, który wpaja w stworzenie poczucie winy, by to czuło się zobligowane do „codziennego podnoszenia Boga z martwych", Nancy zdejmuje z materialnych szczątek złe sumienie: dar bytu był wszakże „darem śmierci”, więc nikt nie jest Bogu winien jego zmartwychwstania. Od kiedy nastał Zachód, żyjemy w świecie wolnej materii, w niepodległym Królestwie Ontologii, w którym wszystko, co jest, istnieje w modi bytu skończonego umożliwionego przez śmierć. Koniec i kropka: „nie ma nic więcej do powiedzenia”, jak często urywa swoje rozważania Nancy.„Opowieść? Nie, żadnych opowieści. Nigdy więcej"23.

21 Przypomnijmy tylko, że la fable métaphysique to termin, jakim Kartezjusz kwituje swoją hipotezę złośliwego demona, której fundamentalne znaczenie w ten sposób neutralizuje, udając, że wizja deus fallax, straszliwego Boga Ukrytego, który wodzi nas na wszelkie pokuszenie, jest tylko drobnym filozoficznym żartem, niewinną bajeczką. Na temat śmiertelnie poważnej stawki, jaką ta „baśń" niejawnie zawiera, zob. mój tekst: Cogito, albo narodziny nowoczesności z ducha gnostyckiego paradoksu. Hansa Blumenberga lektura Kartezjusza, w: Deus Otiosus. Nowoczesność w perspektywie postsekularnej, red. A. Bielik-Robson, M. Sosnowski, Wydawnictwo Krytyki Politycznej, Warszawa 2013.

22 W ten, znów absolutnie literalny sposób, Nancy wykłada scholastyczny koncept materialnego bytu jednostkowego jako locum tenens. Ta dosłowność to, rzecz jasna, zamierzona część metody radykalnego materializmu. Zarazem jednak doskonale potwierdza ona tezę Harolda Blooma, zgodnie z którą zachodzi ścisła korelacja między życiem i zdolnością do używania metafory (tu jeszcze mieści się mimo wszystko witalistyczny Derrida) a śmiercią i bezwzględną literalnością. Por. na ten temat moje „Na pustyni”. Kryptoteologie późnej nowoczesności, Universitas, Kraków 2011.

23 M. Blanchot Szaleństwo dnia, przeł. A. Sosnowski, „Literatura na Świecie” 1996 nr 10, s. 82. Blanchot to częste i ważne źródło inspiracji dla Nancy'ego.




Tymczasem widmontologia - Derridiańska hantologie, a więc także „ontologia nawiedzona" [hantée] - nie rezygnuje z ducha opowieści, przeczuwając, że nie ma opowieści bez ducha właśnie. Pracuje nad mitem Luriańskim, niechętna idei, by Świat sprowadzał się „koniec końców” do szczątków albo do Beckettowskiej „kupy gruzu”. Nie byłoby bowiem wówczas czego a fir mo w a ć - chyba że w gruntownie nieszczerym geście mechanicznego potakiwania, do jakiego chcieliby nas namówić Nietzsche, Deleuze i wreszcie Nancy (a czego szczęśliwie nie czyni sam Beckett, zdecydowanie najuczciwszy w tym gronie). Choć bowiem Derrida nie ma problemu ze złożeniem do "krypty” Boga w jego postaci nieskończonej, nieposzkodowanej i suwerennej, jak nas zapewnia w Wierze $i$ wiedzy, to jednak chciałby go zatrzymać w jego postaci „słabej”, będącej przeciwieństwem ens perfectissimum, a więc jako widma, które nie jest w stanie wywierać bezpośredniej siły w bycie, do jakiego nie należy, i może o sobie tylko p r zy p o m i n a ćc ${ }^{24}$. Krypta nie jest więc dla Derridy jedynie grobowcem, w którym spoczywa boski corpus, to także „schowek”, miejsce sekretno-spektralnego przeżycia Boga, który „nawiedza żywych":

Mieszkaniec krypty jest zawsze żywym umarłym, umarłą istotą, którą chcielibyśmy utrzymać przy życiu, ale już jako umarłą [...] To coś jest ani żywe ani umarłe, ani obecne ani nieobecne: ono spektralizuje. Nie należy do ontologii, do języka Bycia bytów, ani do różnicy między życiem a śmiercią. Wymaga, by użyć neologizmu, widmontologii. Uznamy tę kategorię za nieredukowalną, która czyni możliwym wszystko

24 Tej „słabości” nie należy jednak rozumieć ani w kategoriach Vattimowskiego pensiero debole ani w kategoriach weak theology wypracowanych przez Jacka D. Caputo, autora wpływowej książki interpretującej (zawłaszczającej?) Derridę w duchu radykalnej chrześcijańskiej keno$z y$, The Prayers and Tears of Jacques Derrida. Religion without Religion (Indiana University Press, Bloomington 1997). Zarazem jednak moja wykładnia nie podpada pod zasadę "radykalnego ateizmu", którą w przypadku Derridy mocno ostatnio forsował Martin Hägglund, twierdząc, że skoro Derrida jest rzecznikiem życia skończonego, to nie może on być jednocześnie wyznawcą żadnej, nawet najbardziej heterodoksyjnej religii, która z istoty swojej musi być kultem tego, co "nieposzkodowane" (unverletzt, indemne, immunis, unscathed). Jak widać, moje (ale chyba i Derridy) rozumienie tego, czym może być „religia nowoczesna", bardzo się od tego stanowiska różni. Ta specyficzna religijność cimcum, inspirowana Luriańskim mitem, jest bowiem "religią życia skończonego". Por. M. Hägglund Radical Atheism, Derrida and the Time of Life, Stanford University Press, Stanford 2008. Z kolei bardzo ciekawe (choć nie po mojej myśli) czytanie Derridy jako myśliciela od słabych widm, dobrze wpisującego się w projekt Gianniego Vattimo, zawiera książka Andrzeja Marca Wid-monto-logia. Toeria filozoficzna i praktyka artystyczna ponowoczesności, Bęc Zmiana, Warszawa 2015.

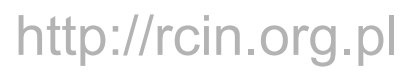


inne: ontologię, teologię, pozytywną bądź negatywną onto-teologię... $(\mathrm{SM}, 51)^{25}$

Zachodnia nowoczesność zatem nie byłaby po prostu wiekiem wyzwolonego ateizmu, który zdekonstruował wszystkie religijne mity, opowiedział do końca wszystkie narracje i wyczerpał, do granic absolutnej dosłowności, wszystkie metafory. W ujęciu Derridy jawi się ona raczej jako wiek „ateologii” urzeczywistniającej się jako boski fade-out, wymazywanie się Boga z solidnych struktur onto-teologicznych po to, by mógł on objawić się w swojej postaci „prawczesnej” (das Frühste): jako Duch, bezcielesne widmo, ruach, żywioł ciągłego, pra-afirmatywnego "poczynania”, wieczny incipit. Ten fade-out ma więc wszystkie cechy ko(s)micznego samozaniku w stylu Kota z Cheshire. Hanter, nawiedzanie, nie jest tu już bowiem tym samym, co straszenie, a zanikanie nie jest tym samym, co „kończenie”. Tym, co pozostaje - i trwa - jest niekończący się uśmiech:

Bo co jeśli, mimo wszystko, nadal byłoby coś do powiedzenia? ${ }^{26}$

25 Szczegółowe dociekania na temat statusu bytowego widma znajdzie czytelnik w kolejnej polskiej książce poświęconej widmontologii: J. Momro Widmontologie nowoczesności. Genezy, Wydawnictwo IBL PAN, Warszawa 2014, zwłaszcza w rozdziale czwartym pt. Obraz mesjański, obraz anarchiczny. Podkreślając polemiczną różnicę między chrześcijańską zasadą pełnego wcielenia a jeszcze niespełnionym mesjanizmem żydowskim, Momro pisze: „Charakter widma opiera się również na paradoksalnym ucieleśnieniu. $Z$ jednej strony staje się ono ciałem, ale z drugiej - owa inkarnacja nie jest całkowita. Widmo jest w pewien sposób cielesne, nie przyjmuje jednak ani formy zjawiska, ani pełnego ciała, cielesnej tkanki, nie przyjmuje fizycznego kształtu (charnelle)" (tamże, s. 472-3). W naszej interpretacji tym, co pozostaje - opierając się zarazem prostej obecności, jak i nieobecności - jest „sam uśmiech", jednocześnie paradoksalnie cielesny i niecielesny.

26 Tym pełnym wahania (ale i nadziei) pytaniem Blumenberg kończy swoje dzieło: Work on Myth, s. 636 . 


\section{Abstract}

\section{Agata Bielik-Robson}

INSTITUTE OF PHILOSOPHY AND SOCIOLOGY OFTHE POLISH ACADEMY OF SCIENCES

UNIVERSITY OF NOTTINGHAM

The Smile of the Spectre with No Body: A Kabbalistic Tale with Derrida in the Background

This essay presents a Kabbalistic interpretation of Derrida's writings. The focus is on Isaac Luria's Tzimtzum, a process in which God surrenders his sovereignty to the created world. In the act of Tzimtzum the Creator withdraws from being, which is then ruled by its own laws. And yet - in contrast to radical deism - God does not disappear completely. His trace remains in the form of his parting smile - a smiling a-dieu. So it is only on the surface that Derrida's spectre, which 'haunts the living,' is a ghost that must be feared. Derrida has no interest in maintaining a threatening divine sovereignty, even as a trace. The Derridean spirit that haunts the world has nothing of the primordial tremens et fascinans of the pagan sacrum about it. It is an entirely different spirit, one that haunts with laughter: the yes-laugh [oui-rire] from Derrida's hauntological article 'Ulysses Gramophone: Hear Say Yes in Joyce'.

\section{Keywords}

Derrida, spectre, Lurianic Kabbalah, Tzimtzum [God's contraction], Joyce, perfect gift 